\title{
Religiosity and intention to whistle blow among Malaysian managers
}

\begin{abstract}
This paper examines the relationship between religiosity and intention to whistle blow among Malaysian managers. Based on 130 responses and using a modified Glock and Starks' religiosity index, the study finds that religiosity and seriousness of wrongdoings are not significantly related to whistle blowing intention. Muslim managers prefer to resolve frauds in stages with wrongdoers being counseled and inculcating a more positive work culture rather than to whistle blow.
\end{abstract}

Keyword: Religiosity; Whistle blowing intention; Whistles blowing; Malaysian managers; Fraud 